\title{
TRTaKadeмi
}

ISSN 2149-9446 | Cilt 07 | Sayı 14 | Ocak 2022 | Sosyal Medya

\section{Kovid-19 Sürecinde Aşı Kararsızlığı: Aşı Karşıtı Tweetlere İlişkin Bir Analiz}

\author{
Nefise ŞiRZAD*
}

\begin{abstract}
Öz
İnternet ve sosyal medya platformlarının gelişimi ile birlikte bilgi üretimi, tüketimi, dolaşımı ve aktarımı bugüne dek hiç olmadığı kadar hızlanmıştır. Ancak doğru ile yanlış sınırlarının belirsizleştiği post-truth döneminde yayılan bu bilgilerin tümünün doğruluğundan söz etmek mümkün değildir. İçinde bulunduğumuz bu dönemde sosyal medya platformları vasıtasıyla oluşan dezenformasyon, bireylerde bilgi karmaşasına neden olmaktadır. Söz konusu karmaşa, birçok alanda olumsuz sonuçlara yol açtığı gibi sağlık alanında da telafisi zor durumlara sebebiyet vermektedir. Özellikle kovid-19 pandemisi sürecinde sosyal medya platformlarında ortaya çıkan yanlış ve yanlı bilgiler insanları sağlık, ekonomik, psikolojik, sosyal vb. birçok açıdan derinden etkilemektedir. Bu çalışmada internet ortamında oluşan dezenformasyonun kararsız bireylerin düşünceleri üzerindeki etkilerine dikkat çekmek amaçlanmıştı. Çalışmada "\#AşıdaPCRdaolmuyoruz" hashtagi ile kovid-19 virüsü, PCR testleri ve kovid-19 aşılarına yönelik paylaşılan 5000 tweet içerik analizi yöntemi ile MAXQDA programında analiz edilmiştir, 11 kategoriye ayrılan bu tweetlerin ne ölçüde bilimsel kaynaklara dayandığı ortaya konulmuştur. En fazla tweet içeren kategoriler sırasıyla, siyasi odaklı içerikler, güvensizlik kategorisi ve hak odaklı açıklamalar kategorisi olmuştur. Analiz sonucunda virüs ve aşı ile ilgili paylaşılan tweetlerin sadece \%5.86'nın bilimsel kaynaklara dayandığı tespit edilmiştir.
\end{abstract}

Anahtar Kelimeler: Dezeformasyon, Bilgi Kirliliği, Sosyal Medya, Kovid-19 Aşısı, PCR Testi

\footnotetext{
* Dr. Öğr. Üyesi, Çankaya Üniversitesi İktisadi ve İdari Bilimler Fakültesi Halkla İlişkiler ve Reklamclık Bölümü, nefise@cankaya.edu.tr
}

Şirzad, N. (2022). Kovid-19 Sürecinde Aşı Kararsızlığı: Aşı Karşıt Tweetlere ilişkin Bir Analiz. TRT Akademi, 7 (14), 58-81. DOI: 10.37679/trta.1010334

\section{Araştırma Makalesi}

Geliş Tarihi: 15.10 .2021

Revizyon Tarihi: 28.11.2021

Kabul Tarihi: 14.01.2022 


\title{
TRTakadeмi
}

ISSN 2149-9446 | Volume 07 | Issue 14 | January 2022 | Social Media

\section{Vaccine Indecision in the Covid-19 Process: An Analysis of Anti-Vaccine Tweets}

\author{
Nefise ŞiRZAD
}

\begin{abstract}
With the development of the internet and social media platforms, information production, consumption, circulation and distribution have been accelerated more than ever before. However, it is impossible to talk about the accuracy of all this information, which spread in the post-truth period, while the boundaries of truth and lie became unclear. In this period, disinformation created through social media platforms causes information confusion in individuals. These decisions lead to negative consequences in many areas, as well as in the field of health, which lead to irreparable consequences. Inaccurate and biased information that emerged on social media platforms, especially during the Covid-19 pandemic process, harms people in terms of health, economic, psychological, social, etc. This study aims to draw attention to the harmful effects of internet disinformation on the thoughts of undecided individuals. In the study, 5000 tweets about the Covid-19 virus, PCR tests and Covid-19 vaccines with the hashtag "\#VaccinationPCRdaolmuz" were analyzed in the MAXQDA program with the content analysis method. These tweets were divided into 11 categories and it was revealed to what extent these tweets were based on scientific sources. The categories with the highest number of tweets were about political issues, insecurity, and rights-based statements. As a result of this analysis, it was determined that only $5.86 \%$ of the tweets shared about the virus and vaccine were based on scientific sources.
\end{abstract}

Keywords: Disinformation, Information Pollution, Social Media, Covid-19 Vaccine, PCR Test 


\section{Giriş}

Çin'de ortaya çıkan virüs ile birlikte çok sayıda yanlış ve eksik bilgi sanal ortamda dolaşmaya başlamıştır. Bu bilgiler resmi ve gayri resmi WEB siteleri vasıtasıyla yayıldığı gibi forumlar, sosyal ağlar, WhatsApp grupları gibi kullanıcı kaynaklı içerikler biçiminde de paylaşıma girmiştir. Pandemi sürecinde paylaşılan bu yalan, eksik ve yanlış bilgiler sanal ortam ve özellikle de sosyal ağlarda dezenformasyona uygun bir zemin oluşturmuştur. Dünya Sağlık Örgütü ve sağlıktan sorumlu kurumlar bir taraftan kovid-19 salgını ile mücadele ederken diğer taraftan da infodemi ile mücadele etmek mecburiyetinde kalmıştır. Dünya Sağlık Örgütü ise kovid-19 ile ilgili oluşan bilgi kirliliğine dikkat çekmek için "infodemi” terimini kullanmıştır.

Birer türetici olan internet kullanıcılarının paylaşımlarının denetimsiz biçimde yayılması, söz konusu içeriklere maruz kalan bireylerin fikirlerini, inançlarını ve gerçeklik algılarını etkileyebilmekte; sağlık, psikolojik, ekonomik ve toplumsal açıdan telafisi zor durumlara yol açabilmektedir. Bu süreç kovid-19 pandemisinden kurtulmanın en önemli unsurlarından biri olarak değerlendirilen kovid-19 aşıları için de aynı şekilde işlemektedir. Aşılar ile ilgili paylaşılan yanlış ve eksik bilgiler, aşı konusunda kararsız bireylerin kararlarını etkileyebilmekte, aşı karşıtı görüşlerin hızla yayılmasına neden olabilmektedir.

Bu çalışmada 20-21 Ağustos tarihleri arasında Twitter ortamında "\#AşıdaPCRdaolmuyoruz" hashtagi ile paylaşılan 5000 tweetin içeriğinin analizi MAXQDA programında gerçekleştirilmiştir, kovid-19 virüsü, aşıları ve PCR testilerine yönelik tweetlerde yer alan düşünceler, bakış açıları ve ifadeler incelenmiştir. Incelemeler sonucunda tweetler 11 kategoriye ayrılmıştır ve her kategorinin dağılımı hesaplanmış, kategoriler, alt kategoriler ve her kategoriye ait tweet sayısı kod teori modeli ile görselleştirilmiş. Tweetlerde en fazla kullanılan kelimeleri ortaya koymak için kelime bulutu ile görselleştirme gerçekleştirilmiştir. Çalışmada incelenmeye alınan tweetlerin yüzde kaç oranında bilimsel kayaklara dayandığı tespit edilmiştir.

20 Ağustos 2021 tarihinde T.C. Sağlık Bakanlığı koronavirüs (kovid-19) riskini asgari seviyeye indirmek amacıyla konser, sinema ve tiyatro gibi vatandaşların toplu olarak bulunduğu faaliyetlere katılım, uçak, otobüs, tren veya diğer toplu ulaşım araçlarıyla gerçekleştirecek şehirlerarası seyahatler için aşı veya negatif sonuçlu PCR testinin zorunluluğu ile ilgili genelge yayınlamıştır. Söz konusu tarihte aşıyı tercih etmeyen/aşı karşıtları bu karar ile ilgili tepkilerini sosyal medyada paylaştıkları tweetler ve oluşturdukları hashtagler ile göstermeye çalışmıştır. Bu nedenden yola çıkarak çalışmada 20-21 Ağustos tarihleri arasında paylaşılan tweetler 
analiz için seçilmiştir.

Bu analiz kapsamında aşağıdaki soruların cevaplanması amaçlanmıştır:

1- "\#AşıdaPCRdaolmuyoruz" hashtagi ile içerik paylaşan bireylerin ve genel anlamda aşı karşıtlarının kovid-19 virüsü, aşısı ve PCR testine karşı olma gerekçeleri nelerdir?

2- Aşı ile ilgili olumsuz/olumlu paylaşımlarda bulunan bireylerin içerikleri ne ölçüde bilimsel kaynaklara dayanmaktadır?

Tüm dünyayı etkisi altına alan bu hastalık ile ilgili insanlarda oluşan kaygı, onları sanal ve gerçek ortamda bilgi arayışına sürüklemektedir. Ancak bu bireylerin yanlış ve yalan bilgilere maruz kalması ile birlikte bir taraftan salgınla mücadele diğer taraftan psikolojik savaş ile karşı karşıya kaldıkları aşikârdır. Kovid-19 salgını, sanal ortamda bilgi kirliliğinin ciddi bir sorun olduğunu karşımıza çıkarmaktadır.

\section{Post-Truth Döneminde Sosyal Medya Dezenformasyonu}

Sosyal medya mecraları post-truth olgusunu beslemekte, yalan ve yanlış bilgilerin dolaşımını hızlandırmaktadır. Post-truth kavramının kullanımına 1992 yılından itibaren başlanmıştır ancak 2016 yılında Amerika'da Trump'ın başkanlık seçimleri, İngiltere'deki Brexit referandumu süreci ve Oxford sözlüğünün bu kavramı "yılın kelimesi" olarak seçmesi ile popüler hâle gelmiştir. Hakikat ötesi, hakikat sonrası, gerçek ötesi olarak Türkçeye çevrilen bu kavram "kamuoyunu şekillendirmede nesnel gerçeklerin duygulardan ve kişisel inançlardan daha az etkili olması" şeklinde tanımlanmaktadır (Oxford Dictionaries). Özünde manipülasyon ve algı yönetimi olan bu kavram özellikle siyasette kitleleri yönlendirmek için kullanılmaktadır.

\footnotetext{
"Post-truth, hakikat ile yalan arasındaki sınırların bulanıklaştığı, duyguların ve inançların gerçeklerden daha çok itibar gördüğü bir dönemi ifade etmektedir. Bu dönemde aldatmak ve birtakım çıkarlar doğrultusunda insanların algılarıyla oynamak normalleştirilmeye çalışımaktadır" (Aydın, 2020).
}

Post-truth çağında, internet kullanıcıları çevrim içi ortamda dolaşan bilgilerin doğruluğunu araştırmadan kendi inançları, düşünceleri, çıkarları ile örtüştüğüne inandıkları bilgileri kabul etmekle kalmayıp, doğruluğundan emin olmadıkları bilgileri yaymaktadır. Hatta bazı durumlarda bu bilgilerin asılsız olduğunun farkına vardıktan sonra bile yaymaya devam etmektedir.

Etkileşimsiz WEB olarak bilinen WEB 1.0 dönemi internet kullanıcılarına çevrim 
içi içerikleri okuma, izleme ve duyma imkânı sunarken; WEB 2.0 ve sosyal medya mecralarının internet kullanıcılarına WEB 1.0'ın sunduğu imkânların yanı sıra içeriklere müdahale ve diğer kullanıcılar ile etkileşimde bulunma olanağı da sağlamaktadır. WEB 2.0 kullanıcıları forumlarda, bloglarda, şikâyet WEB sitelerinde ve Facebook, Twitter gibi sosyal ağlarda kendi duygularını, düşüncelerini, memnuniyetlerini veya memnuniyetsizliklerini ifade etmektedir. Bu bağlamda WEB 2.0 olgusu içerik üreticilerini, birer türeticiye dönüştürmektedir. Bu kullanıcılar çevrim içi ortamdaki içerikleri tüketirken (consumer), aynı zamanda içerik üreticisi (producer) rolünü de üstlenmektedir. Çevrim içi ortamda türeticilerin oluşması, bu kişilerin duygularının, düşüncelerinin ve bilgilerinin herhangi bir kontrolden geçmeden yayılması, bir taraftan bireylere ifade özgürlüğü, etkileşim ve katılım gibi olanaklar sunarken diğer taraftan çevrim içi ortamda bilgi kirliliği ve dezenformasyona yol açmaktadır. Sosyal medya mecralarında internet kullanıcıları isteyerek veya istemeden yanlış ve yanlı bilgileri aktardıkları için bu ortamlar hem dezenformasyon hem de misenformasyon kaynağı olarak tanımlanabilir. Misenformasyon, yanlış bilginin kasıtsız olarak paylaşılması; dezenformasyon ise yanlış bilginin zarar vermek için kasıtlı olarak paylaşılması biçimde tanımlanmaktadır (Wardle ve Derakhshan, 2017). Bu çalışma kapsamında genel anlamda yanlış ve yanlı bilginin paylaşımı söz konusu olduğundan dezenformasyon kavramının kullanımı tercih edilmiştir.

Geleneksel ve sosyal medya karşılaştırmasında sosyal medya mecralarının dezenformasyon kaynağı olma açısından geleneksel mecralara kıyasla daha yüksek bir potansiyele sahip oldukları söylenebilir. Haber yayım kaynağı olarak bilinen kitle iletişim araçlarında içerik filtrelenmesi, denetim mekanizması ve "eşik bekçilik" mekanizması bulunmaktadır. Eşik bekçileri, bir mesajın kaynaktan hedef kitleye giderken el değiştirdiği kişilerdir. Eşik bekçilerinin görevi, bir bireyin aldığı mesajları gerek çalıştı̆ı yayın organının politikasına, gerek meslek etiğine, gerekse kişisel kanaatlerine göre süzgeçten geçirmektir (Mutlu, 2017, s. 110). Geleneksel medyada okuyuculara ve izleyicilere ulaştırılan bilgiler, eşik bekçileri tarafindan sayısız enformasyon içinden seçilmektedir (Kafiliveyjuyeh ve IIlhan, 2017. s. 29). Ancak kullanıcı güdümlü içeriklerin dijital medya ortamında oluşturulduğu için bu ortamda herhangi bir denetim mekanizmasından söz etmek mümkün olmamaktadır. Profesyonel bir denetim mekanizması ve doğru bilgi süzgecinin bulunmaması sosyal medyada bilgi kirliliğine yol açmakta, bu ortamı dezenformasyon kaynağına dönüştürmekte, yalan ve yanlış haberlerin yayılımına neden olmaktadır. "Yalan haberi bir eleştirel farkındalık sorununun ötesinde, sosyal gerçekliğin sınırları üzerinde yürütülen politik bir mücadelenin parçası olarak 
değerlendirmek önemlidir" (Taş, 2018).

Twitter gibi sosyal medya mecraları yalan haberlerin dolaşım hızını artırmaktadır. 2006'dan 2017'ye kadar Twitter'da 3 milyon kişi tarafindan 4,5 milyondan fazla tweetlenen, 126.000 doğrulanmış ve yanlış haberin yayılımını inceleyen Vosoughi ve arkadaşlarının (2021) araştırmasına göre yanlış haberler doğru haberlere kıyasla, daha hızlı ve daha etkili bir biçimde yayılmakta, daha geniş kitlelere ulaşmaktadır. Bu haberlerin olumsuz etkileri terörizm, doğal afetler, bilim, şehir efsaneleri veya finansal bilgilerden ziyade yanlış siyasi haberler için daha belirgindir. Tweetlerdeki sahte haberler korku, iğrenme ve şaşkınlık duygularını uyandırırken gerçek haberler beklentiye, üzüntüye, neşeye ve güvene sebep olmaktadır. Twitter mecrasında 10 yıldan fazla bir süredir 3 milyon kullanıcı tarafindan tweetlenen ve yaklaşık 126.000 hikâyeyi içeren, İngilizce dilinde yayınlanan, tartışma konusu olan haber hikâyelerini analiz eden ve gerçeğin aldatmaca ve söylenti ile rekabet edemeyeceğini ortaya koyan bir MIT araşttrmasına göre ise Twitter'daki yalan gerçeğe hâkimdir. Bu kapsamda sahte haberler ve yanlış söylentiler, daha fazla insana ulaşmakta, sosyal ağın daha derinlerine inmekte ve doğru hikâyelerden çok daha hızlı yayılmaktadır (Meyer, 2021). Amerika Birleşik Devletleri'nde 1 Ekim 2017'de en ölümcül kitlesel silahlı saldırısı olan Las Vegas saldırısıyla ilgili yayınlanan tweetlerin gönderildiği zaman, tweet metni, tweet konumları ve bu gibi 150'den fazla veri değişkenini inceleyen araştırmaya göre, tweetlerdeki popüler iddialar arasında silahlı saldırıdan DEAŞ'ın sorumlu olduğu, saldırganın Antifa'nın bir üyesi olduğu ve saldırganın bir Müslüman olduğu iddiaları yer almıştır. Tespit edilen yanlış iddiaların sayısının, düzeltme girişiminde bulunan tweet sayısından çok daha fazla olduğu tespit edilmiş, konu ile ilgili yeni oluşturulan gerçek tweetlerin, yanlış iddiaları sürdüren tweetlere göre çok daha hızlı azaldığı görülmüştür (Blankenship ve Graham, 2020).

Son yıllarda, sosyal medya platformları yanlış içeriğin yayılmasını sınırlamak için girişimlerde bulunduklarını duyurmuştur. 2015 ve 2018 yılları arasında, 569 sahte haber WEB sitesinde yer alan yalan haberleri ve Facebook ve Twitter'da yayınlanan 9540 sahte haber içeriğine yönelik eğilimleri ölçen Allcott ve arkadaşlarının araştırmasına (2019) göre 2016'nın sonuna kadar sahte içeriklere yönelik kullanıcı etkileşimleri hem Twitter'da hem de Facebook'da istikrarlı bir şekilde artmıştr. Ancak o tarihten itibaren Facebook'da yanlış içeriklerle etkileşimin ciddi bir ölçüde azalmasına rağmen, Twitter'da yükselmeye devam etmiştir. Söz konusu tarihlerde sahte haberlere yönelik Facebook etkileşimleri Twitter paylaşımlarına göre \%60 oran ile azalmıştır. Bu araştırma Facebook'daki yanlış bilgi sorununun göreceli büyüklüğünün azaldığını göstermiştir. 
Sosyal medya ortamında yeni medya okuryazarlığı bilgisinden yoksun olan, araştırmadan paylaşılan tüm bilgileri doğru kabul eden ve bu bilgileri kullanan bireyler filtre balonu olgusuna uymaktadır. Bu olguya göre "sosyal ağ kullanıcılarını kendi inanç ve eğilimlerindeki kişi ve içeriklerle karşılaştırdığından, kullanıcılar farklı fikirlerden izole olarak zaten benimsedikleri fikirlere daha da sarılmaktadırlar" (Narin, 2018). Söz konusu bireyler kendi duygu, düşünce, inanç ve çıkarlarını destekleyen kişilere güvenmekte, bu kişiler tarafindan oluşturulan bilgileri sorgulamadan bilinçli veya bilinçsiz bir biçimde doğru kabul etmekte, uygulamakta ve yaygınlaştırmaktadır. Filtre balonu olgusuna toplumsal olaylarda, afetlerde ve kriz dönemlerinde sıklıkla rastlanılmakta, yalan ve yanlış bilgilerin sosyal ağlarda dolaşımı söz konusu dönemlerde hız kazanmaktadır. Bu durumun en yakın ve en etkili örneklerinden birisi kovid-19 salgını olarak karşımıza çıkmaktadır.

\section{Sosyal Medya ve İnfodemi}

Internet kullanımın yaygınlaşması ile birlikte internet, sağlık alanında da etkili bir bilgi edinme aracına dönüşmüştür. Sağlıkla ilgili konularda internet mecrası, bilgi ve görüş edinmek için yaygın biçimde kullanılmaktadır. Sosyal medyanın denetimsiz kullanımı, kullanıcıların sağlık deneyimlerini doğrudan paylaşmalarına ve sağlık odaklı şirketlerin mesajlarının herhangi bir kontrolden geçmeden gönderilmesine ve yayılmasına olanak sağlamaktadır. Bu nedenle, sağlık alanında resmi ve bilgili bir kaynağın süzgecinden geçmeden doğru ve yanlış sağlık bilgisi sosyal medyada paylaşılabilmekte hatta bazı durumlarda sosyal medya kullanıcıları, sadece şirketlerin ticari kazançları için tasarlanan ve yayınlanan diğer kullanıcıların yanlış bilgilerine veya sağlık mesajlarına maruz kalmaktadır. İş hedefleri, ticari çıkarlar ve yanlış kişisel düşünceler ile karıştırılan yanlış sağlık temalı içerikler internet ortamında dezenformasyona ve misenformasyona yol açarak kararsız veya sağlık bakımından zor durumda olan ve çare arayışında olan bireylerin sağlık problemleri ile ilgili kararlarını olumsuz etkileyebilmektedir.

Kovid-19 pandemisi sürecinde Türkiye hükûmeti, virüsle mücadele kapsamında kamuoyunu bilgilendirmek açısından sosyal medya mecralarını etkin biçimde kullanmıştır. "Türkiye'de sosyal medya kullanıcıları kovid-19 kriziyle ilgili bilgilenmede en güvenilir bilgi kaynağı olarak "Sağlık Bakanı Fahrettin Koca’yı” görmektedir. Sağlık bakanından çok daha az oranda olmak kaydıyla da ikinci sırada "Sağlık Bakanlığı WEB Sayfası" yer almaktadır" (Çerçi vd., 2021). Ancak devlet yetkililerinin tüm çabalarına rağmen birçok sosyal medya kullanıcısı, farkında olup/olmadan dezenformasyon taşıyıcısı olabilmektedir.

Kovid-19 ile ilgili yanlış bilgilerinin içeriğini, zamanlamasını ve yayılmasını tweet- 
ler üzerinden inceleyen bir araşttrmaya göre kovid-19'a ilişkin yanlış bilgilendirme tweetleri daha spesifik olmayan otorite bireyler (örneğin, "Tayvanlı uzmanlar", "bir doktor arkadaşı", "üst düzey sağlık görevlileri") tarafindan paylaşılırken, bu tweetleri çürüten ve yanlışlığını ortaya koyan tweetler daha spesifik ve doğrulanabilir otorite kaynaklar (örneğin, CDC, Dünya Sağlık Örgütü, Snopes) tarafindan paylaşılmaktadır (Mcglynn vd., 2020).

"Dijital araçların bilgiye ulaşmada öncelikli tercih hâline gelmesi nedeniyle pandemi döneminde özellikle sosyal medyada "infodemi" olarak tanımlanan aşırı enformasyon akışı ortaya çıkmıştır" (Akyüz, 2021). "Information” (Enformasyon) ve "epidemic" (salgın) kelimelerinin birleştirilmesinden ortaya çıkan "infodemi” kavramı, 2003 yılında SARS ile bağlantılı olarak kullanılmış, kovid-19 salgını sırasında 31 Mart 2020 tarihinde Dünya Sağıı Örgütü (DSÖ) tarafindan tekrar kullanılmaya başlanmıştır, küresel düzeyde yeniden gündeme gelen bir kavram olmuştur. İnfodemi, DSÖ (2020) tarafindan salgın sırasında dijital ve fiziksel ortamlarda yanlış veya yanıltıcı bilgiler içeren çok fazla bilgi olarak tanımlanmaktadır. Sağlığa zarar verebilecek, kafa karışıklığına ve risk alma davranışlarına neden olan infodemi, aynı zamanda sağlık yetkililerine güvensizliğe de yol açmaktadır. Dünya Sağlık Örgütü Genel Direktörü Dr. Tedros’un, daha salgının başlarında yaptığı, "Biz sadece bir pandemiyle değil aynı zamanda bir infodemiyle de savaşıyoruz." açıklaması ile birlikte gözler bilgi kaynaklarına çevrilmiştir.

Türkiye'nin ilk doğruluk kontrolü organizasyonlarından biri olan teyit.org'un salgın boyunca infodemi hakkındaki gözlemleri ve tespitlerine göre internet kullanıcıları en çok yanlış bilgiye salgının ilk zamanlarında maruz kalmış, salgın ilerledikçe ilgi yitirilmiştir. İnfodemi kapsamında en çok maruz kalınan yanlış bilgiler ise hatalı ilişkilendirilen görüntüler, belgeler, haritalar, kovid-19 virüsünün özellikleri, sahte tedavi yöntemleri, ilaçları ve salgının ortaya çıkışı ve yönetimi ile ilgili komplo teorileri olmak üzere dört kategoride toplanabilir (Gölbaşı ve Metintaş, 2020).

Çevrim içi toplulukların pandeminin ilk aşamalarında "infodemiye" nasıl katkıda bulunduğunu anlamak için Twitter'de bulunan en aktif aşı hesaplarından gelen içerikleri inceleyen Jamison ve arkadaşları (2020) hem aşı karşıtlarının hem de aşı savunucularının, Twitter'da kovid-19 "infodemisine" etkili olduğunu ortaya koymuştur. Bu inceleme sonucunda sadece aşı karşıtlarının kovid-19 hakkında yanıltıcı bilgiler paylaşmadığını, aşı savunucuları tarafindan da güvenirliği bulunmayan iddiaların yayıldığı görülmüştür. Kovid-19 pandemisi sırasında medya tüketimi, yanlış bilgilendirme ve tutum ve davranışlar arasındaki ilişkiyi inceleyen Bridgman ve arkadaşlarına (2020) göre haber medyası, sosyal mesafe gibi halk sağlığı tavsiyelerini güçlendirme eğilimindeyken Twitter'da nispeten daha fazla 
yanlış bilgi dolaşmaktadır. Sosyal medya kovid-19 hakkındaki temel gerçeklerle ilgili yanlış algılamalara yol açarken haber medyası için tam tersi söz konusudur. Bu yanlış algılamalar, sosyal mesafe önlemlerine uyma ihtimalini düşürmektedir.

\section{Kovid-19 Pandemisinde Sağlık Bilgisi Arayışı}

Internetsiz bir gün bile geçirmekte zorlanan bireyler, sosyal medyayı eğitim, ticaret, iletişim, gibi alanlarda etkin biçimde kullandıkları gibi sağlık alanında da etkili bir biçimde kullanmaktadırlar. Bu kullanıcılar, sağlıkla ile ilgili cüzi sorunlarından, kanser gibi ciddi hastalıklarına kadar sağlık sorunlarının çözümü için ilk aşamada internette arama yapmayı tercih etmektedir. Sağlık arama davranışında internetin sık kullanımı siberkondri (internette hastalık arama hastalığı) olarak bilinen ruhsal probleme neden olmaktadır (Baumgartner ve Hartmann, 2011; Karaer vd., 2012; Altındiş vd., 2018).

Sağlık hizmetlerine erişimin oldukça kısıtlı olduğu yıllarda, hastane veya hekime ulaşma imkânı olmayan insanlar ailelerinden, akrabalarından ve arkadaş gruplarından aldıkları önerilere göre tedavilerini gerçekleştirirken günümüzde tedavi önerilerine; tavsiye siteleri, bloglar, sosyal paylaşım ağları gibi sosyal medya platformlarından ulaşılmaktadır. (Tosyalı ve Sütçü, 2016). Online sağlık bilgisi arama internetteki en yaygın aktiviteler arasına girmiş, yalnızca yazılı bilgi ile sınırlı kalmayarak sesli ve video aracılığıyla görüntülü paylaşımlar da bilgiye ulaşma açısından tercih edilirliğini arttırmıştır. Uzmanlar ve doktorlar sağlığın her alanı ile ilgili bireyin ihtiyaç duyacağı düzeydeki bilgiyi sosyal ağlar üzerinden paylaşmakta ve hatta ilaç kullanımı, alternatif tedavi yöntemleri, destekleyici ürün kullanımı konularında da yönlendirici içerikler üretmektedir.

Sosyal medyanın tekil kullanıcılar açısından hastalıkları ve sorunları konusunda bilgi edinmek ve araştırma yapmak amacıyla kullanılmasının yanı sıra sağlık profesyonelleri açısından; klinik araştırmalar/denemeler için denek bulma, sağlık uzmanları için eğitim ve profesyonel gelişim, profesyoneller arası iletişim ve koordinasyon, eğitim simülasyonları; sağlık konusundaki diğer sosyal ağlar, sağlık ve hastalık destek grupları; sağlık savunuculuğu ve sağlık organizasyonları için bağış; popüler sosyal medya platformlarına eklentilerin ve kişisel yönetim araçlarının geliştirilmesi; halk sağlığı konusunda mesajların yayılması; bulaşıcı hastalıkların izlenmesi gibi farklı amaçlar için kullanılması da söz konusudur. (Gencer vd., 2019).

Kovid-19 pandemisi sürecinde internet ve sosyal medya mecraları söz konusu hastalığın tedavi yöntemleri ve farklı ülkelerin ürettiği aşıların güvenirliği ve et- 
kinliğini sorgulamak bakımından etkili bir biçimde kullanılmıştır. Bununla birlikte aşı karşıt grupları da kendi düşüncelerini, gerekçelerini ve bakış açılarını sunmak üzere sosyal mecraları tercih etmiştir. "Aşılama kadar aşı karşıtığı da eskidir. Aşı karşıtları kurdukları dernekler, çıkardıkları kitaplar, broşürler ve dergilerle aşıların zararlı olduğuna dair çeşitli argümanlar kullanmış, aşılama oranlarında ciddi düşüşlere neden olmuştur. Maalesef başarılı oldukları dönem ve coğrafyalarda insanlar ciddi salgınlarla karşılaşmıştır." (Kutlu ve Altındiş, 2018).

\section{Kovid-19 Aşısına Yönelik Yaklaşımlar}

Çin'in Hubei eyaletindeki Wuhan kentinde küresel bir salgın hâlini alan koronavirüs salgını tüm dünyayı etkisi altına alırken sosyal ağlarda hastalığın tanısı, tedavisi, hastalıktan korunma gibi pek çok konuda bilgi kirliliği oluşmaya başlamıştır. Hastalığın ortaya çıktı̆ı ilk günden itibaren bir taraftan insanlar hastalığa karşı uygulanması gereken korunma tedbirleri, maske, fiziksel mesafe, hijyen önlemleri, hastalıktan korunmak için bitkisel ve tıbbi ilaçlar hakkında bilgi bombardımanı ile karşı karşıya kalmıştır. Diğer taraftan ise korona virüsünün ilk vakası ile birlikte aşılarla ilgili tartışma ortaya çıkmaya başlamıştır. Dünyayı saran korona virüs kâbusuna karşı en büyük silah olarak tanımlanan aşılanma, birçok bilim kurulu üyesi ve sağlık uzmanı tarafindan önerilirken bazı kişiler tarafindan reddedilerek bazılarında ise kararsızlığa yol açmıştır.

Tarih boyunca salgın hastalıkların önlenebilmesi, toplumsal bağışıklığın sağlanması ile mümkün olduğu yadsınamaz bir gerçektir. "Aşılama karşıtı manipülasyonlarla ilgili UNICEF'in Doğu Avrupa'da yaptığı bir çalışmada, blog, forum ve sosyal medyanın yaygın olarak kullanıldığı gösterilmiştir. Çalışmada, aşı karşıtı argümanları yaymada en sık blogların kullanıldığı gösterilirken, argümanların dile göre farklılık gösterdiği, İngilizce yayınlarda en sık komplo teorileri ve dini/etik kaygılara yer verilirken, Rusça yayınlarda dini/etik kaygıların, lehçe yayınlarda ise aşıların yan etkileri ve içerdiği toksin maddeler yer aldığı bildirilmiştir" (Ataç ve Aker, 2014).

Aşı, sadece bireyin kendisi ile kalmayıp bireyin yaşadığı toplumu da doğrudan etkilemektedir.

\footnotetext{
"Aşılama, enfeksiyon hastalıklarından korunmanın yanı sıra, enfeksiyon hastalıkları nedeni ile oluşan ciddi sakatlıkların veya ölümlerin azaltılmasında da en etkin yöntemdir. Bu nedenle aşı kararsızlığını önlemek için gereksinim duyulan stratejilerin, ülkelertemelindegeliştirilmesivetakibenküreselbirstratejikyaklaşımınbenimsenmesi gereklidir" (Erkekoğlu vd., 2020).
} 
Türkiye'de 2009 ile 2018 yılları arasında aşılanma ile ilgili yapılan çalışmaları irdeleyen Filiz ve Kaya'ya (2019) göre “Türkiye'de aşılar hakkında bilgilerin yüksek oranlarda internet sitelerinden veya sosyal medyadan sağlandığı, sağlık merkezlerinden bilgi sağlama oranlarının düşük olduğu ve aşılama önündeki en büyük engelin konu ile ilgili bilgisizlik olduğu görülmüştür."

İnsanların duygu ve düşünce ifade özgürlüğü sunan sosyal medya mecraları kovid-19 aşısına karşıt kişilere düşüncelerini aktarma firsatı sunmaktadır. Bu paylaşımlar bilimsel kanıtları görmezden gelen, değişik sosyo-ekonomik ve kültürel yapıdaki kişilere ulaşarak bu bireylerin kararsızlığa düşmelerine ve aşı karşıtı grupların sayısında artışa neden olabilmektedir. Ataç ve Aker (2014) aşı karşıtlarını, kâr/zarar ilişkisini yeterli görmeyenler, risk altında olmadığını düşündüğü için ihtiyaç hissetmeyenler ve dini, felsefi veya komplo temelli gerekçelerle aşılara itiraz edenler olarak 3 gruba ayırmaktadır (Ataç ve Aker, 2014). Amerika'da 1640 kişi üzerinde yapılan "YouGov" anketi, Amerikalıların \%28'inin Bill Gates'in insanların vücuduna chip takmasını mümkün kılmak amacıyla aşı olmaya teşvik edildiklerine inandıklarını gösteriyor, Cumhuriyetçiler arasında bu oran \%44'e yükseliyor (Goodman ve Carmichael, 2020).

Kovid-19 gibi bulaşıcılığı ve yaşamı tehdit etme riski yüksek salgınlarda, bireylerin kendileri ve yakınlarının enfekte olmasına dönük korku ve kaygıları bireysel boyuttan toplumsal boyuta taşınmaktadır. Salgının Türkiye'de görüldüğü ilk haftayı takip eden süreçte gerçekleştirilen bir araştırma, katılımcıların oldukça yüksek bir oranla ilk sırada ailelerinin/tanıdıklarının virüse yakalanmasından korktuklarını göstermektedir. Katılımcıların ikinci yüksek korku kaynağını ise kalabalık yerlerde virüse maruz kalmak olarak açıklamaktadır. (Doğan ve Düzcel, 2020) Yiğit vd. (2021) kovid-19 konusunda yaptıkları betimsel analizde, aşı tereddüdü yaşayan, aşıyı reddetmiş olan ve Türkiye'nin çeşitli illerinde yaşayan 83 ebeveyn ile yaptıkları görüşmede aşı karşıtlığı fikrini edinen profilin sosyo-kültürel ve sosyo-ekonomik, gelir düzeyleri yüksek, az çocuklu ebeveynlerden oluştuğunu, bu bireylerin araştırmacı ve sorgulayıcı kişilik özelliklerine sahip olduğunu ve aşı karşıtlığı fikrini modern tıp uygulamalarına karşı muhalif bir tavır ve bireysel bir tavır sonucunda ortaya çıktığını tespit etmişler. Akyüz'ün (2021) şeffaflık, yanlış bilgiye maruz kalma düzeyleri ve aşı karşıt iddialara ilişkili yürüttüğü araştırmasına göre ise aşı karşıt iddialarla ilgili tutum "orta” düzeyde iken, aşı karşıtı tutum arttıkça aşı kararsızlığının da arttğı görülmektedir. En yüksek katılımın "Koronavirüsün laboratuvarda üretildiği” iddiasına yönelik olduğu görülürken koronavirüs aşılarıyla insanın DNA'sının değiştirileceği iddiasına orta düzey katılım olmuştur (Akyüz, 2020). 
Kovid-19 aşıları ile ilgili dijital ortamda paylaşılan içeriklerin büyük bir ölçüde bilimsel kaynaklara dayanmadan üretilip paylaşılması, bu paylaşımların dezenformasyona yol açmasına ve bireylerin sağlığını, ekonomik, sosyal, toplumsal ve bireysel ilişkilerini olumsuz yönde etkilenmesine yol açmaktadır.

\section{Metodoloji}

Bu çalışmanın yapılabilmesi için sosyal medyanın temel biçimlerinden olan ve toplumsal bir aktör niteliği taşıyan Twitter mecrasından yararlanılmıştır. Twitter'ın toplumsal olaylarda bir aktör olmasının yanı sıra sosyal sorumluluk içeren etkinliklerde de önemli bir payı olmaktadır (Yıldırım, 2014).

Sosyal medyanın bir çeşit bilgilenme ve bilgilendirme aracı hâline geldiği günümüzde kovid-19 virüsü ile ilgili yanlı, doğruluk payı bulunmayan ve şüphe uyandıran tweetlere dikkat çekmek amacıyla çalışmada 20-21 Ağustos tarihleri arasında Twitter mecrasından \#AşıdaPCRdaolmuyoruz hashtagi ile yayınlanan 6472 tweete Twitter API'sı(Application Programming Interface-Uygulama Programlama Arayüzü) üzerinden ulaşılmıştır. Ulaşılan tweetlerin $141^{\prime}$ i erişim kısıtlı olduğu için görüntülenememiştir, 615'i tweet cevap biçiminde (retweet) yayınlandığı için çalışmaya dahil edilmemiş ve 716 tweet herhangi bir yazı olmadan sadece \#AşıdaPCRdaolmuyoruz hashtagi ile yayınlandığı için analiz dışı bırakılmıştır. Analiz dışı bırakılan tweetler göz önüne alındığında, "\#AşıdaPCRdaolmuyoruz" hashtagi ile yayınlanan 5000 tweet bu araştırmanın örneklemini teşkil etmiştir. Tweetler içerik analizi yöntemi ile MAXQDA 2020 programı kullanılarak analiz edilmiş, zorunlu aşı ve PCR testine ilişkin tepkiler, tutum ve bakış açıları ortaya konulmuştur. İçerik analizi yöntemi, "Metin içinde tanımlanan belirli karakterlerden sistematik ve tarafsız sonuçlar çıkarmak için kullanılan bir araştırma tekniğidir" (Stone vd., 1966, s. 213). Bu yöntemde "temelde yapılan işlem, birbirine benzeyen verileri belirli kavramlar ve temalar çerçevesinde bir araya getirmek ve bunları okuyucunun anlayabileceği bir biçimde düzenleyerek yorumlamaktır" (Yıldırım ve Şimşek, 2011 s. 227). İçerik analizi; özellikle teknik avantajlar söz konusu olduğunda, materyal ya da verinin fazla olduğu ve araştırmacının yorumlama yeteneğini aşthğ durumlarda kullanılan bir yöntemdir (Altunışık vd., 2015, s. 3246).

Bu çalışmada modelin doğru kurulması ve frekansların elde edilmesi için veri setinin ön okuması yapılmış, örneklemin yüzde 10'luk dilimini (bkz. O'Connor ve Joffe, 2020) temsilen 500 tweet kodlanarak kategoriler belirlenmiştir. Araştırmanın güvenilirliğini artırmak amacıyla tweetler iki farklı kodlayıcı tarafindan eş zamanlı olarak eş zamanlı kodlama yöntemi ile kodlanmıştır. 
Fikir ayrılığı yaşanan kategorilerin tweetleri tekrar incelenerek revize edilmiş ve uzlaşı sağlanmıştır (Tablo 1).

Kodlama kategorileri, tweetlerin kategorilere göre dağılımı ve kategorinin açıklaması tablo 1'de yer almaktadır. Tweetler için tekil kodlama yapılmış ve her tweet sadece bir kategoriyi temsil edecek biçimde kodlanmıştır. Doğru bir analizin gerçekleşmesi için tweetlerde paylaşılan makaleler, video ve fotoğraf biçimindeki tweetlerdeki mesajlar dikkatle ele alınmış kodlamaya dâhil edilmiştir.

Tablo 1. Kodlama Tablosu

\begin{tabular}{|c|c|c|c|}
\hline Tema & $\begin{array}{l}\text { Tweet Sayısı } \\
\text { (n) }\end{array}$ & Açıklama & Yüzde \\
\hline $\begin{array}{l}\text { Siyasi Odaklı } \\
\text { Açıklamalar }\end{array}$ & 1070 & $\begin{array}{l}\text { Bu kategoride politik ya da partisel } \\
\text { bazlı yaklaşımlar yer almaktadır. } \\
\text { Bu tweetlerde aşı ve zorunlu PCR } \\
\text { testinin darbe, } 28 \text { Şubat olayları, } \\
\text { başörtüsü sorunlarıyla benzerlik ta- } \\
\text { şıdığına dikkat çeken söylemler yer } \\
\text { almaktadır. Genel olarak zorunlu } \\
\text { aşı ve PCR testinden dolayı devlete } \\
\text { yönelik isyan ve serzenişler bu kate- } \\
\text { goride bulunmaktadır. }\end{array}$ & $\% 21.40$ \\
\hline Aşıya Güvensizlik & 860 & $\begin{array}{l}\text { Aşının yan etkileri, sebep olduğu } \\
\text { hastalıklar ve ölümler, aşılanmaya } \\
\text { rağmen vaka artışının ve ölüm sayı- } \\
\text { sının azalmamasına dair söylemler } \\
\text { bu tweet grubunda yer almaktadır. } \\
\text { Aşının hastalığın iyileşmesinde et- } \\
\text { kisiz olduğuna işaret eden tweetler } \\
\text { bu kategoriyi oluşturmaktadır. }\end{array}$ & $\% 17.20$ \\
\hline $\begin{array}{l}\text { Hak Odaklı } \\
\text { Açıklamalar }\end{array}$ & 857 & $\begin{array}{l}\text { Bu kategorideki tweetler aşılanmayı } \\
\text { hukuka, akla, bilime, mantı̆g, vic- } \\
\text { dana, insan hak ve özgürlüklerine } \\
\text { saldırı olarak kabul etmektedir. } \\
\text { Mecbur kılmak, şantaj, tehdit, bas- } \\
\text { kı, zorlama, mecburiyet, mobing } \\
\text { gibi kavramlarla hak arayışında } \\
\text { bulunan bireylerin ifadeleri bu } \\
\text { kategoride yer almaktadır. "Benim } \\
\text { bedenim, benim kararım" mantı̆ı } \\
\text { ile tweetler paylaşımıştır. }\end{array}$ & $\% 17.14$ \\
\hline
\end{tabular}




\begin{tabular}{|c|c|c|c|}
\hline Ayrımcılık & 598 & $\begin{array}{l}\text { Aşı olanlar ve olmayanların birbir- } \\
\text { lerine yönelik söylemleri, tepkileri, } \\
\text { yaklaşımları, tartışmaları ve halkın } \\
\text { bölündüğüne işaret eden tweetler } \\
\text { bu kategoride yer almaktadır. Tu- } \\
\text { ristler ve göçmenler için herhangi } \\
\text { bir aşılanmma zorunluluğunun bu- } \\
\text { lunmadığından şikâyetçi bireylerin } \\
\text { tweetleri de bu kategoride değer- } \\
\text { lendirilmiştir. }\end{array}$ & \%11.96 \\
\hline Provokasyon & 368 & $\begin{array}{l}\text { İnsanları aşı yaptrrmamak için ikna } \\
\text { edici ifadeler, hukuki bilgilendirme- } \\
\text { ler, kararsız bireyleri aşı yaptırma- } \\
\text { mak eylemine davet eden cümleler } \\
\text { bu kategoride yer almaktadır. }\end{array}$ & $\% 7.36$ \\
\hline $\begin{array}{l}\text { İoni } \\
\text { Değerlendirmeler, } \\
\text { Trollemek }\end{array}$ & 340 & $\begin{array}{l}\text { Konuyu ciddiye almayan, esprili } \\
\text { ve alaycı bir yaklaşımla konuya } \\
\text { yaklaşan ve bazı anlamsız ifadeler } \\
\text { ve videolar bu kategoride yerini } \\
\text { almıştır. }\end{array}$ & $\% 6.80$ \\
\hline Bilimsel Açıklamalar & 249 & $\begin{array}{l}\text { Doktorların, bilim insanlarının, } \\
\text { kovid-19 ve kovid-19 aşısının avan- } \\
\text { tajları ve dezavantajları ile ilgili } \\
\text { beyanları, bilgilendirmeleri ve kanıt } \\
\text { sunmaları bu kategoride yer almak- } \\
\text { tadır. Hukukçuların da aşı zorun- } \\
\text { luluğu ile ilgili hukuki beyanları bu } \\
\text { kategoride bulunmaktadır. }\end{array}$ & $\% 4.98$ \\
\hline Fikir alışverişi- Öneri & 228 & $\begin{array}{l}\text { Bu kategoride kovid-19, aşı ve PCR } \\
\text { testi ile ilgili öneriler, merak edilen } \\
\text { sorular ve destek talepleri yer al- } \\
\text { maktadır. }\end{array}$ & $\% 4.56$ \\
\hline Komplo Teorileri & 120 & $\begin{array}{l}\text { Kovid-19 virüsü ve aşıların bazı } \\
\text { ülkelere ve bazı firmalara avantaj } \\
\text { sağladığı için ortaya çıktığını ve tica- } \\
\text { ri bir tuzak olduğunu savunan twe- } \\
\text { etler bu kategoride yer verilmiştir. }\end{array}$ & $\% 4.40$ \\
\hline Ticari Tuzak & 206 & $\begin{array}{l}\text { Aşı ile birlikte çipler takıldığını, } \\
\text { virüsün ve aşın küreselcilerin ya } \\
\text { da hükûmetin bir oyunu olduğunu } \\
\text { savunan açıklamalar bu kategoride } \\
\text { yer almıştı. }\end{array}$ & $\% 2.12$ \\
\hline Dini Söylemler & 104 & $\begin{array}{l}\text { Konu ile ilgili ayetler, hadisler, dini } \\
\text { alınt biçimindeki sözler ve vecizeler } \\
\text { bu kategoride yer almaktadır. }\end{array}$ & $\% 2.08$ \\
\hline Total & 5000 & & $\% 100$ \\
\hline
\end{tabular}


\#AşıdaPCRdaolmuyoruz hashtagi ile iki gün içerisinde paylaşılan 5000 tweetin içeriklerinin analizi sonucunda söz konusu tweetler 11 kategoriye ayrılmıştır. Tablo1'de de açıklandığı gibi zorunlu aşı ve test ile ilgili yayınlanan tweetlerin \%21.40'ında kovid-19 aşısı ve testine ilişkin siyasi odaklı içerikler yer almaktadır.

Bu tweetlerde aşı ve PCR testinde zorunluluktan dolayı devlete yönelik tepkiler görülmektedir. Aşının işe yaramadığını iddia eden ve aşıyı yaptıranların da virüse yakalandığını savunan aşıyı yönelik güvensizliği aktaran tweetler incelenen tweetlerin toplam \%17.20'sini oluşturmaktadır. Zorunlu aşının insan hak ve özgürlüklerine aykırı olduğunu savunan tweetler örneklem tweetlerinin \%17.14'ünü temsil etmektedir. Tweetlerin \%11.9'u zorunlu aşı ve testin ayrımcılığa sebep olduğunu savunan ve aşılanmanın turistlere zorunlu olmadığına itirazda bulunan tweetlerden oluşturmaktadır. İnsanları aşı yaptırmamaya teşvik eden ve onları zorunlu test ve aşıya yönelik provoke eden tweetler \%7.36 oranla bir diğer kategoride yer almaktadır. Doktorlar, bilim insanları ve avukatların kovid-19 ve alınan karar ile ilgili bilgilendirici ifadelerini içeren tweetler toplam tweetlerin \%4.98'ini oluşturmaktadır. Tweetlerin \%4.56'sı kovid-19, zorunlu aşı ve PCR test ile ilgili merak edilen soruları, süreç ile ilgili önerileri ve düşünce paylaşımını kapsamaktadır. Kovid-19 virüsü ve aşısını kabullenemeyen ve bu konunun komplo teorilerden ibaret olduğunu ifade eden tweetlerin oranı \%4.12 olmuştur. Virüsün ve aşının güçlü ülkeler ve dev firmalar tarafindan ticari kazanç elde etmek için ortaya çıktğını ifade eden tweetler toplam tweetlerin \%2.40'ını oluşturmaktadır. Bu tweetlerin \%2.08'inde ise ayetler, hadisler ve vecizeleri yer almaktadır.

Araştırma kategorileri ve yüzdelerini grafiksel olarak paylaşmak amacıyla kategoriler ve frekans değerleri şekil 1'de sütün grafiği ile de gösterilmiştir.

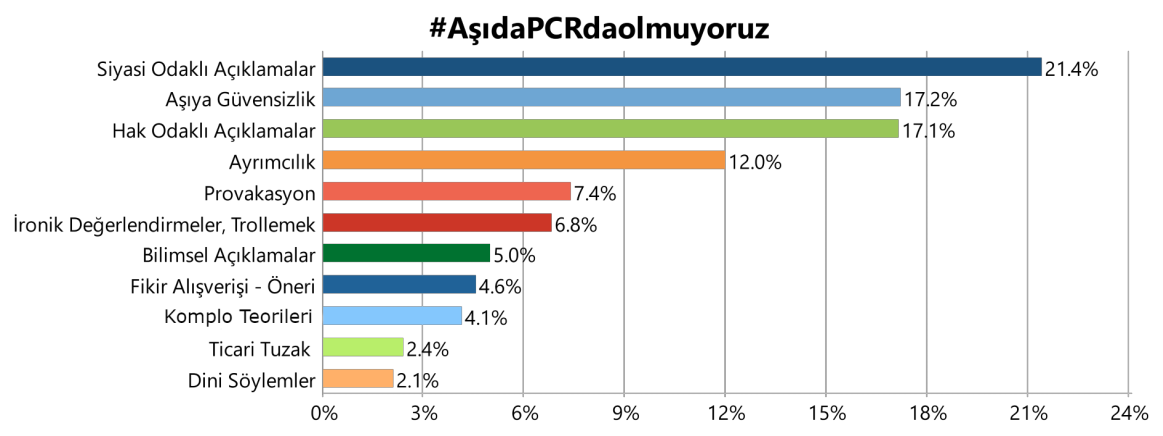

Şekil 1. \#AşıdaPCRdaolmuyoruz Hashtagi ile Paylaşılan Tweetlerin Kategorileri 
MAXQDA programında yapılan analiz sonucunda \#AşıdaPCRdaolmuyoruz hashtagine ilişkin kategoriler kod teori model ile görselleştirilmiştir.

\section{\#AşıdPCRdaolmuyoruz}

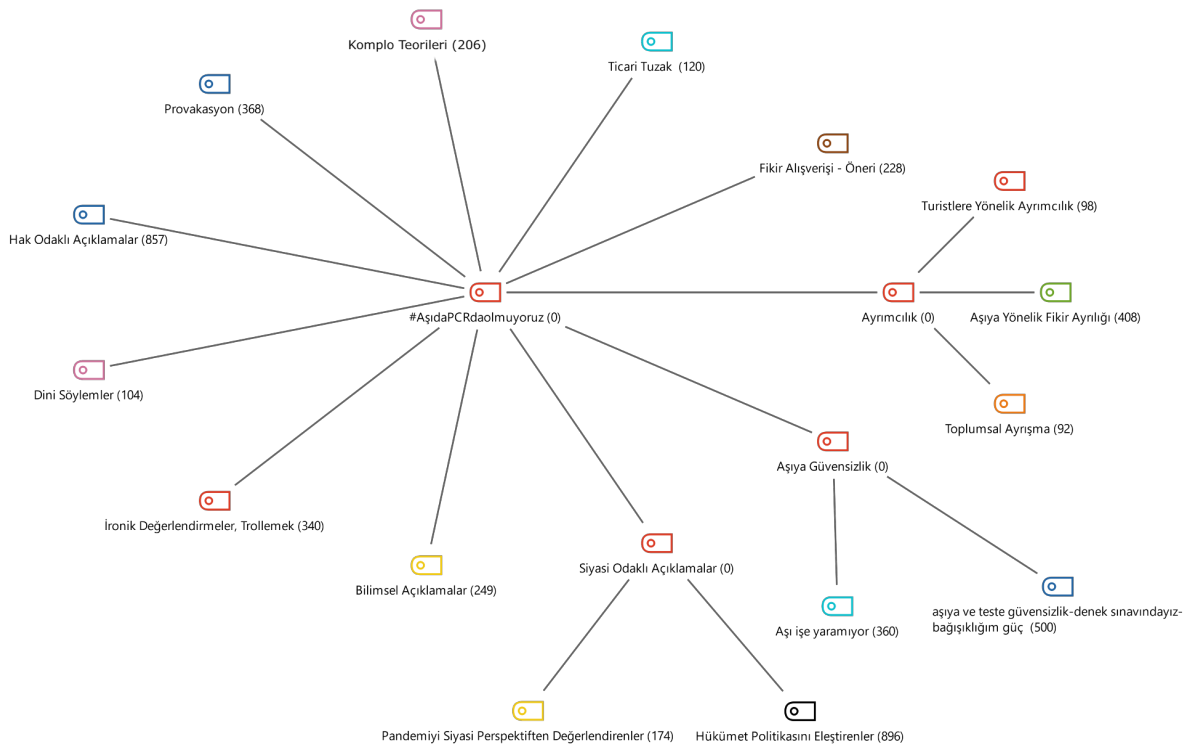

Şekil 2. \#AşıdaPCRdaolmuyoruz ile İlgili Kod Teori Modeli

Bu modelden yola çıkarak \#AşıdaPCRdaolmuyoruz hashtagi ile paylaşılan tweetlerin ( $n=5000$ ) içerik analizi sonucunda tweetler 11 üst kategoriye ayrılmıştır. Bu üst kategoriler içerisinden en fazla tweet içeren kategori siyasi odaklı açıklamalar ( $n=1070$ ) kategorisi olmuştur. Analizi daha anlaşılır hâle getirmek ve detaylandırmak amacıyla siyasi odaklı açıklamalar kategorisi, pandemiyi siyasi perspektiften değerlendiren açıklamalar ( $n=174)$ ve hükûmet politikalarını eleştiren açıklama$\operatorname{lar}(n=896)$ olmak üzere iki alt kategoriye ayrılmıştrr. En fazla tweet içeren ikinci kategori olan güvensizlik üst kategorisi $(n=860)$ aşı ve teste yönelik güvensizlik ( $n=500)$ ve aşının işlevselliği ile ilgili güvensizlik $(n=360)$ olmak üzere iki alt kategoriye ayrılmıştır. Ayrımcılık üst kategorisi ( $n=560)$ ise, turistlere yönelik ayrımcılık ( $n=98)$, aşıya yönelik fikir ayrılığı $(n=408)$ ve toplumsal ayrışama $(n=92)$ alt kategorilerine ayırılmıştır.

Twitter mecrasının büyük bir veri kaynağı olması, doğru ve yanlış bilgilerin herhangi bir bilimsel süzgeçten geçmeden bu ortamda yayınlanması ve herkese açık olması, paylaşılan tweetlerin kararsız bireylerin kararlarını etkileme potansiyeline sahip olması ve çalışmada incelenmeye alınan \#AşıdaPCRdaolmuyoruz 
hashtaginin günlerce trend topic olması çalışma kapsamında incelenen tweetlerin ne ölçüde bilimsel kaynaklara dayandığını göstermeyi gerekli kılmaktadır. Bu makalede tweetlerin içeriği analiz edilirken paylaşılan tweetlerin herhangi bir bilimsel dayanağının olup olmadığı incelenmiştir. Bu incelemeler sonucunda paylaşılan tweetlerin yüzde kaç oranında bilimsel ve hukukî deliller ve kanıtlara bağlı paylaşıldığı kategoriler bazında tablo 2'de verilmiştir.

Tablo 2. Tweetlerin Kaynaklarının Dağılımı

\begin{tabular}{|c|c|c|}
\hline Kategori & Bilimsel kaynak var & Bilimsel kaynak yok \\
\hline Siyasi Odaklı Açıklamalar & $n=0$ & $\begin{array}{l}n=1070 \\
(\% 100)\end{array}$ \\
\hline Aşıya Güvensizlik & $\begin{array}{l}n=139 \\
(\% 16)\end{array}$ & $\begin{array}{l}n=721 \\
(\% 84)\end{array}$ \\
\hline Hak Odaklı Açıklamalar & $\begin{array}{l}n=46 \\
(\% 5)\end{array}$ & $\begin{array}{l}n=811 \\
(\% 95)\end{array}$ \\
\hline Ayrımcılık & $n=0$ & $\begin{array}{l}n=598 \\
(\% 100)\end{array}$ \\
\hline Provokasyon & $n=0$ & $\begin{array}{l}n=368 \\
(\% 100)\end{array}$ \\
\hline $\begin{array}{l}\text { İroni Değerlendirmeler, } \\
\text { Trollemek }\end{array}$ & $n=0$ & $\begin{array}{l}n=340 \\
(\% 100)\end{array}$ \\
\hline Bilimsel Açıklamalar & $\begin{array}{l}n=108 \\
(\% 43)\end{array}$ & $\begin{array}{l}n=141 \\
(\% 57)\end{array}$ \\
\hline Fikir Alışverişi- Öneri & $n=0$ & $\begin{array}{l}n=228 \\
(\% 100)\end{array}$ \\
\hline Komplo Teorileri & $n=0$ & $\begin{array}{l}n=206 \\
(\% 100)\end{array}$ \\
\hline Ticari Tuzak & $n=0$ & $\begin{array}{l}n=120 \\
(\% 100)\end{array}$ \\
\hline Dini Söylemler & $n=0$ & $\begin{array}{l}n=104 \\
(\% 100)\end{array}$ \\
\hline Total & $\begin{array}{l}n=293 \\
(\% 5.86)\end{array}$ & $\begin{array}{c}n=4707 \\
(\% 94.14)\end{array}$ \\
\hline
\end{tabular}

Tweetlerin içeriklerinin analizi sonucunda oluşan kategorilerden sadece aşıya güvensizlik, hak odaklı açıklamalar ve bilimsel açıklamalar kategorilerindeki tweetlerin yurt içi ve yurt dışı kaynaklı bilimsel ve hukuksal kanıtlara, araştırmalara ve makalelere dayanarak paylaşıldığı tespit edilmiştir. Bu tweetlerde söz konusu bilimsel kaynaklara link verme veya YouTube'a yönlendirme ile ulaşılmıştır. Bazı durumlarda ise bilimsel kaynaklar tweet içerisinde kısa video vasıtasıyla paylaşılmıştır. Aşıya güvensizlik kategorisi çerçevesinde paylaşılan 860 tweetten 139'u (\%16'sı), hak odaklı açıklamalar kategorisinden 857 tweetten 46'sı (\%5'i), bilimsel 
açıklamalar kategorisinden 108'i (\%43'ü) ve toplam 5000 tweet içerisinden 293 tweet (toplam tweetlerin \%5.86'sı) bilimsel kaynaklar referans gösterilerek paylaşılmıştır. Diğer kategorilerdeki tweetlerin hepsi öznel ve doğruluğu kanıtlanmamış, kişisel ifadelerden oluşmuştur. Bilimsel açıklamalar kategorisinde doktorlar, avukatlar ve bilim insanları tarafindan paylaşılan tweetlerin ise sadece \%43'ünün bilimsel kaynaklar gösterilerek paylaşılması çalışmanın dikkat çekici noktalardan birisi olmuştur.

\#AşıdaPCRdaolmuyoruz hashtagi ile paylaşılan tweetlerin değerlendirilmesi sonucunda şekil 2'de yer alan kelime bulutu ortaya çıkmıştır. Özet ve görselleştirme amacıyla metindeki içerikleri ve temaları sunmak için kelime bulutları yaygın olarak kullanılmaktadır (Xu, 2016). "Kelime bulutu metin belgelerinin en yaygın sözcüklerini görsel olarak iletmek için basit ve etkili bir araçtır" (Lohmann, 2015). Aşı ve PCR testi ile ilgili bireylerin düşüncelerini ifade eden tweetlerde en fazla kullanılan kelimeleri gösteren kelime bulutunda "aşı, PCR, testi, haftada, haftada, istemiyorum, neden zorunlu, zorla, hakkı, yok, niçin insanlara dayatma, olanlar, olmayanlar, devlet" kelimelerinin daha yoğun kullanıldığı tespit edilmiştir.

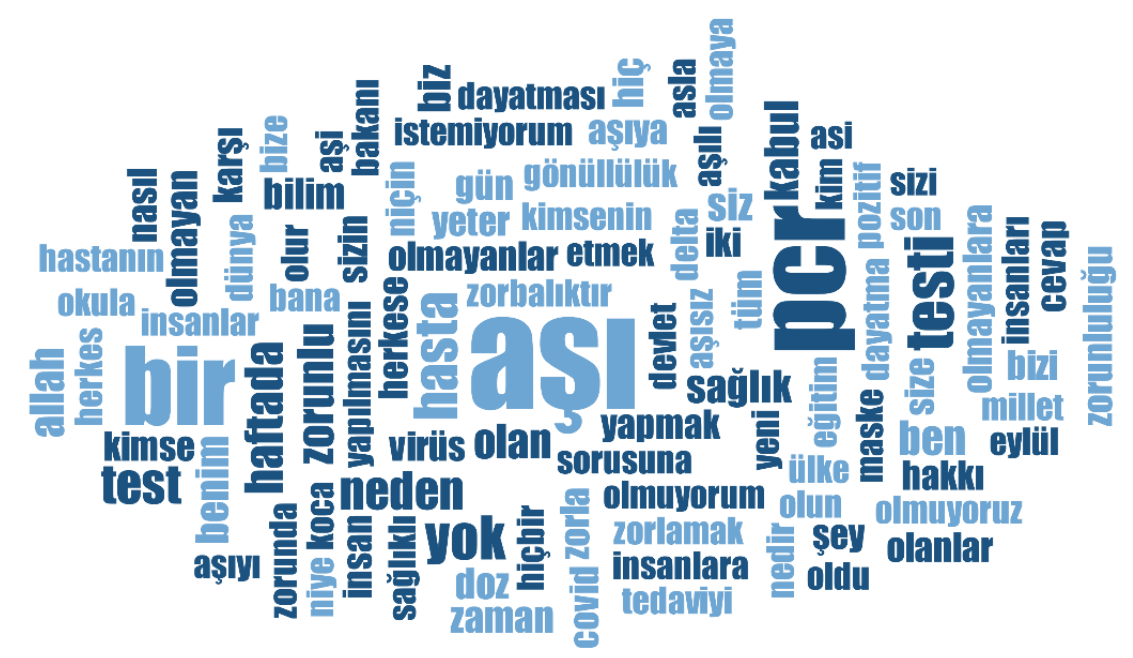

Şekil 3. \#AşıdaPCRdaolmuyoruz Kelime Bulutu

\section{Tartışma ve Sonuç}

Sosyal medya mecralarının kullanıcılarına doğrudan içerik üretme ve paylaşma imkânı sağladığı için doğru ve yanlış bilgiler eş zamanlı olarak bu ortamda dolaşıma girmektedir. Paylaşılan yanlış, abartılı, yanlı ve doğruluğu kanıtlanmamış bilgiler sosyal medya ortamında dezenformasyon ve bilgi kirliliğine sebep olmaktadır. 
Söz konusu paylaşımlar doğru bilgi ile yanlış bilginin arasındaki sınırların kalkmasına ve telafisi zor ve çoğu zamanlar telafisi mümkün olmayan sonuçların ortaya çıkmasına neden olmaktadır. Sosyal medya mecraları vasıtasıyla oluşan dezenformasyon sağlık ile ilgili durumlar söz konusu olduğu zamanlarda daha fazla önem arz etmektedir.

Aralık 2020 yılında Çin'de görülen ilk kovid-19 vakasının ardından virüsün ortaya çıkış nedenleri, tedavisi ve aşıları hakkında WEB siteleri, sosyal medya mecraları ve mesajlaşma uygulamalarında paylaşılan yanlış ve yanlı bilgiler sanal ortamda oluşan dezenformasyonun belirgin bir göstergesidir. Kovid-19 hastalığı için tek umut olan aşılar üretilmeye başlandığından itibaren bu aşıların güvenirliliği hakkında çeşitli iddialar ortaya atılmış ve aşıya olumlu yaklaşmayan bireyler doğru/ yanlış bilgilerini özgürce herhangi bir denetim mekanizmasından geçmeden internet ortamında paylaşmıştır. Ancak bu paylaşımların kararsız bireylerin düşüncelerini etkileyebilme potansiyeline sahip olması yadsınamaz bir gerçektir.

Aşı ve PCR testinin zorunlu hâle geleceği ile ilgili kararın duyurulduğu tarihte söz konusu karara ilişkin tepkileri içeren 5000 tweet bu çalışma kapsamında incelenmiştir, tweetlerin ne ölçüde bilimsel kaynaklara dayandığı tespit edilmiştir. \#AşıdaPCRdaolmuyoruz hashtagi ile paylaşılan tweetlerin incelenmesi sonucunda tweetler 11 kategoriye ayrılmıştır. Sözü edilen kategoriler, siyasi odaklı açıklamalar, aşıya güvensizlik, hak odaklı açıklamalar, ayrımcılık, provokasyon, ironi değerlendirmeler, bilimsel açıklamalar, fikir alışverişi-öneri, komplo teorileri, ticari tuzak ve dini söylemler olarak isimlendirilmiştir. İncelemeler sonucunda Twitter kullanıcılarının zorunlu PCR testi ve aşı ile ilgili tepkilerini en fazla siyasi odakIı içerikler (\%21.40) ile gösterdikleri, paylaştıkları içeriklerde ise devlet ve siyasi partilere yönelik isyanlar ve serzenişlerin yoğun olarak yer aldığı tespit edilmiştir. En fazla tweet içeren ikinci kategorinin güvensizlik (\%17.20) kategorisi olduğu, Twitter kullanıcılarının aşı, test ve aşının işlevselliği ile ilgili güvensizlik duygusunu barındırdıkları gözlemlenmiştir. Zorunlu aşı ve test ile ilgili en çok tweet paylaşılan diğer kategori ise hak odaklı açıklamalar kategorisi olmuştur. Twitter kullanıcıları zorunlu aşılanmayı hukuka, akla, bilime, mantığa, vicdana, insan hak ve özgürlüklerine saldırı olarak değerlendirmiştir. Kovid-19 virüsü ve aşısıyla ilgili paylaşılan 5000 tweetten yalnızca 293'ü ya da farklı bir ifadeyle sadece \%5.86'sı bilimsel kaynaklara dayanarak paylaşılmıştır. Diğer tweetlerde aktarılan bilgilerin ise, bireylerin öznel bilgi, düşünce ve bakış açılarına dayandığı görülmüştür. Bu çalışma ile internet ortamında oluşan, paylaşılan ve kararsız bireylerin kararlarını etkileme potansiyeline sahip olan kullanıcı güdümlü içeriklerin bir denetim mekanizmasına dayanmadığının ve bu gerçeğin tüm alanlarda özelliklede sağlık alanında 
büyük krizlere yol açabileceği konusunun alt çizilmiştir.

Kovid-19 aşısına olumlu yaklaşmayan ve aşı karşıtlığı düşünceleri besleyen tweetlerin analizi ile internet ortamında ortaya çıkan dezenformasyona dikkat çekmeyi amaçlayan bu çalışmadan elde edilen sonuçların literatürde yapılan çalışmalara benzer ve destekleyici nitelikte olduğu ifade edilebilir. Koray ve arkadaşlarının (2020) kovid-19 pandemisi sürecinde Twitter ortamında oluşan dezenformasyon ile ilgili yaptıkları çalışmada 637 tweet incelemiştir. Kovid-19 salgınıyla ilgili 14 farklı trend hashtag ve anahtar kelimenin incelendiği bu çalışmaya göre tweetlerin çoğunun (\%66) resmi olmayan kişiler/gruplar tarafindan, \%19'u doğrulanmış twitter hesaplarından paylaşılmıştır. Bu tweetlerden \%24,8'i yanlış bilgi içerirken, \%17,5'i Kovid-19 salgınıyla ilgili doğrulanamayan bilgiler içermiştir. Resmî olmayan bireysel/grup hesaplarında yanlış bilgi oranı daha yüksek düzeyde (\%33.8) tespit edilmiştir. Bir diğer benzer çalışmada Aydın (2020) Türkiye'de ilk koronavirüs vakasının görüldüğü 11 Mart 2020 tarihinden itibaren 1 haftalık süre içerisinde, kovid-19 virüsü ile ilgili sosyal medyada yayılan şüpheli haberleri analiz ederek haberlerin doğruluğunu veya yanlışlığını ortaya koyan teyit.org doğrulama platformundan yararlanmıştir. Bu incelemeler sonucunda söz konusu zaman içerisinde paylaşımlar/haberlerin hepsinin yanlış olduğunu tespit etmiştir.

Başka bir çalışmada Karakaş ve Doğru (2021) "dogrulukpayi.com" ve "teyit.org," isimli haber doğrulama WEB siteleri vasıtasıyla kovid-19 aşılarına ilişiklin iddiaları bir aylık süre içerisinde incelemiştir. Bu incelemeler sonucunda yeni medyada kovid-19 aşılarına yönelik üretilen içeriklerin, post-truth kavramının yapısına uygun biçimde, dezenformasyon yayan niteliklerde olduğu saptanmıştır. Bu gönderilerin çoğunun gerçeği yansıtmadığını, çarpıtılmış, bağlamından koparılmış ya da tamamen yalan içeriklerden oluştuğu ortaya konulmuştur. Aşı ile ilgili yapılan bir diğer çalışmada ise Porsuk ve Cerit (2021), kovid-19 aşıları hakkındaki eğilimleri anlamak amacıyla Ekşi Sözlük'te açılan başlıkları incelemiştir. Incelemeleri sonucunda yaklaşık bir yıllık bir süre içerisinde (21.01.2020 ve 14.01.2020), konu ile ilgili 1142 başlığın açıldığı tespit edilmiştir. İncelenen başlıkların \%58,2'si "Spekülasyon", \%24,9'u "Tartışma”, \%11,3'ü “Mizah" ve \%5,6'sı "Haber" olarak kategorize edilmiştir. Twitter gibi sosyal medya platformlarının yol açth̆ı siyasi ve enformasyonel kutuplaşmanın halk sağlığı adına korkunç sonuçları olduğunu savunan Havey (2020), kovid-19 pandemisi ile ilgili 4000'den fazla tweet incelemiştir. Bu analiz çerçevesinde incelenen tweetlerde tedavi olarak hidroksiklorokin kullanımı; önleyici tedbir olarak çamaşır suyu kullanımı, virüse kasıtlı bir biçimde yol açan Bill Gates, virüse kasten neden olan Çin Komünist Partisi ve virüsün ekonomiyi mahvetmesi ve Başkan Trump'ın yeniden seçilme şansını tehdit eden 
Derin Devlet şeklinde alt yanlış bilgilendirme konusu tespit edilmiştir. 6 konunun 5 'inde (çamaşır suyu hariç), muhafazakârların Twitter'daki söylemlere hâkim olduğu tespit edilmiştir. Muhafazakârların ayrıca, Çin Komünist Partisi, Bill Gates ve Derin Devlet'in nüfusu etkilemek ve bir gözetim devletini yürürlüğe koymak için birlikte çalıştı̆ına dair komplo teorilerine liberal akranlarından daha fazla inandığı görülmüştür. Bu araştırma, pandemi ile ilgili yanlış bilgilerin halk sağlığı tavsiyelerine bağıılığı azaltth̆̆ını ve sağlık üzerindeki olumsuz etkilere yol açtı̆̆ını bulgulamıştır. Mevcut pandemiden elde edilen kanıtlar, halk sağlığı tavsiyelerine bağ|ılığın tamamen partizan olduğunu göstermiştir.

Çalışmada elde edilen bulgular sonucunda genel olarak internet ve sosyal medya platformlarının yanlış ve doğrulanmamış bilgilerin hızlı ve denetimsiz yayılması için uygun zemin hazırladığını söylemek mümkündür. Bu durumun ise, dijital medya okuryazarlığı düşük olan kararsız bireylerin karar mekanizmalarını olumsuz yönde etkileyebilmesinin mümkün olduğunu ve pandemi gibi bir dönemde bireylerin yaşadıkları bu kararsızlıkların ve bilgi karmaşasının, karar verme süreçlerinde istenmeyen etkilere yol açabileceğini varsaymak mümkündür. Bu sebeplerden dolayı sosyal medyada yer alan paylaşımların ciddiyetle ele alınması ve değerlendirilmesi gerekmektedir.

\section{Çıkar Çatışması Beyanı}

Makale yazarları herhangi bir çıkar çatışması olmadığını beyan etmiştir.

\section{Kaynakça}

Akyüz, S. (2021). Aşı karşıtlığı ve şeffaflık algısında iletişim pratikleri ve siyasal aidiyetlerin rolü. Yeni Medya Elektronik Dergisi, 5 (2), 172-185.

Alcott, H. ve Gentzkow, M. Yu. C (2019). Trends in the diffusion of misinformation on social media, Research and Politics,1-8.

Aydın, A. F. (2020). Post-Truth dönemde sosyal medyada dezenformasyon: Covid-19 (yeni koronavirüs) pandemi süreci. Asya-Akademik Sosyal Araştırmalar, 4(12), 76-90.

Bridgman, A., Merkley, E., Loewen, P. J., Owen, T., Ruths, D., Teichmann, L., \& Zhilin, O. (2020). The causes and consequences of COVID-19 misperceptions: Understanding the role of news and social media. Harvard Kennedy School Misinformation Review, 1(3).

Çerçi, Ü. Ö. , Canöz, N. ve Canöz, K. (2020). Covid-19 krizi döneminde bilgilenme aracı olarak sosyal medya kullanımı. Selçuk Üniversitesi Sosyal Bilimler Enstitüsü Dergisi, 44, 184-198. 
Ataç, Ö. ve Aker, A. A. (2014). "Aşı karşıtlığı”. Sağlık Düşüncesi ve Tıp Kültürü Dergisi, 30 (1): 42-47.

Erkekoğlu P., Erdemli Köse S. B., Balcı A. ve Yirün A. (2020) .Aşı kararsızlığı ve Covid-19’un etkileri, Eczacılık Bilimleri Dergisi 9(2):208-220.

Filiz, M. \& Kaya, M. (2019). Systematic review of studies to determine factors affecting vaccine rejection / instability / contrast. Turkish Research Journal of Academic Social Science, 2 (2) , 1-7.

Goodman, J. ve Carmichael, F. (2020). “Coronavirus: Bill Gates 'microchip' conspiracy theory and other vaccine claims fact-checked". https://www.bbc.com/ news/52847648 (Erişim Tarihi: 25.10. 2021).

Gölbaşı S. ve Metintas S. (2020). Covi-19 pandemisi ve infodemi. ESTÜDAM Halk Sağlığı Dergisi, 5(Special Issue), 126-137.

Havey, N.F. (2020). Partisan public health: How does political ideology influence support for COViD-19 related misinformation, Journal of Computational Science, 3,319-342.

Kutlu, H.H. ve Altındiş, M.(2018). Aşı karşıtlığı, FLORA İnfeksiyon Hastalıkları ve Klinik Mikrobiyoloji Dergisi, 23(2), 47-58.

İnfodemy, https://www.who.int/health-topics/infodemic\#tab=tab_1 (Erişim Tarihi, 2 $0.10 .2021)$.

Jamison, M. A., Broniatowski, D. A., Dredze, M., Sangraula, A., Smith, M. C. \& Quinn, S. C. (2020). Not just conspiracy theories: Vaccine opponents and proponents add to the Covid-19 'infodemic' on Twitter. Harvard Kennedy School (HKS) Misinformation Review.

Kafiliveyjuyeh, S., ve İlhan, E. (2017). Sosyal ağ çağında eşik bekçisinin değişen rolü. Yeni Medya, 28-50.

Karakaş, O. ve Doğru, Y. B. (2021). Covid-19 aşılarına yönelik üretilen yeni medya içeriklerinin post-truth kavramı bağlamında analizi. Asya Studies, 5 (16), 163-182.

Kouzy R, Abi Jaoude J, Kraitem A, El Alam MB, Karam B, Adib E, Zarka J, Traboulsi C, Akl EW \& Baddour K.(2020). Coronavirus goes viral: Quantifying the Covid-19 misinformation epidemic on Twitter. Cureus.12(3).

Mcglynn, J., Baryshevtsev, M. and Dayton, Z,A. (2020). Misinformation more likely to use non-spesific authority references: Twitter analysis of two Covid-19 myths, Harvard Kennedy School Misinformation Review, 1 (Special Issue on COVID-19 and Misinformation).

Meyer, R. (2021). "The grim conclusions of the largest-ever study of fake news". https:// www.theatlantic.com/technology/archive/2018/03/largest-study-ever-fakenews-mit-twitter/555104/ (Erişim Tarihi: 02.10.2021) 
Memiş D, M. ve Düzel, B. (2020). Covid-19 özelinde korku-kaygı düzeyleri. Turkish Studies, 15(4), 739-752.

Mutlu, E. (2017). İletişim sözlüğü. İstanbul: Ütopya.

Narin, B. (2018). Kişiselleştirilmiş çevrim içi haber akışının yankı odası etkisi, filtre balonu ve siberbalkanizasyon kavramları çerçevesinde incelenmesi. Selçuk iletişim, 11 (2), 232-251.

O' Connor, C. \& Joffe, h.(2020). Intercoder reliability in qualitative research: Debates and practical guidelines. International Journal of Qualitative Methods, 19.

Oxford Dictionaries (2016). “Word of the year 2016. https://languages.oup.com/word-ofthe-year/2016/ (Erişim Tarihi: 25.08.2021).

Özdemir, D. ve Arpacıoğlu, S. (2020). Sosyal medya kullanımı, sağlık algısı ve sağlık arama davranışının korona virüs korkusu üzerine etkisi. Psikiyatride Güncel Yaklaşımlar 12(1), 364-381.

Porsuk, A. Ö. ve Cerit, Ç. (2021). Sosyal medyada covıd-19 aşısı tartışmaları: Ekşi sözlük örneği. Hacettepe Sağlık İdaresi Dergisi, 24 (2), 347-360.

Lohmann, S., Heimerl, F., Bopp, F., Burch, M. \& Ertl, Th.(2015).Concentri cloud: Word cloud visualization for multiple text documents, International Conference on Information Visualisation, 114-120.

Stone P. J., Dunphy D. C., Marshall S. S. \& Ogilvie D.M, (1966). The general inquirer: A computer approach to content analysis. Massachusetts: The M.I.T. Press.

Gencer, T. Z. , Daşlı, T. Y., ve Biçer, E . (2019). Sağlık iletişiminde yeni yaklaşımlar: Dijital medya kullanımı. Selçuk Üniversitesi Sosyal Bilimler Meslek Yüksekokulu Dergisi, $22(1), 42-52$.

Taş, O. ve Taş, T. (2018). Post-Hakikat çağında sosyal medyada yalan haber ve Suriyeli mülteciler sorunu. Galatasaray Üniversitesi Illetişim Dergisi, 29, 183-208.

Topsakal, T. ve Ferik, F. (2021). Haber sitelerinin Covid-19 aşılarına yönelik yaklaşımı ve haber içeriklerinin değerlendirilmesi, Akdeniz Üniversitesi İletişim Fakültesi Dergisi, 0 (35).

Tosyalı, H ve Sütçü, C. (2016). Sağlık iletişiminde sosyal medya kullanımının bireyler üzerindeki etkileri. Maltepe Üniversitesi İletişim Fakültesi Dergisi, 3 (2), 3-22.

Vosoughi, S., Roy, D., \& Aral, S. (2018). The spread of true and false news online. Science (New York, N.Y.), 359(6380), 1146-1151.

Wardle, C. \& Derakhshan, H. (2017). Information disorder: Toward an interdisciplinary framework for researchand policy making. Strasbourg: Council of Europe.

Yıldırım, A. (2014). Bir halkla ilişkiler aracı olarak twitter: T.C. sağlık bakanlığı örnek incelemesi. Gümüşhane Üniversitesi İletişim Fakültesi Elektronik Dergisi, 2 (4), 234-253. 
Yıldırım, A. ve Şimşek, H. (2011). Sosyal bilimlerde nitel araştırma yöntemleri. Ankara: Seçkin Yayıncılık.

Yılmaz, N ve Keskin, Ö.H.(2020). Doğruyu "Teyit": Teyit'in Covid-19 infodemisi ile sekiz aylık macerası. Türk Tabipler Birliği, Covid-19 Pandemisi Altıncı Ay Değerlendirme Raporu.644-654.

Yiğit, T., Oktay Ö. B., Özdemir C.N. ve Moustafa Pasa S. (2020). Aşı karşıtlığı ve fikri gelişimi. International Journal of Social Humanities Sciences Research (JSHSR) 7(53):12441261.

Yüksel, G ve Topuzoğlu A. (2019).Aşı retlerinin artması ve aşı karşıtığını etkileyen faktörler. ESTÜDAM Halk Sağlığı Dergisi. 4(2): 244-258. 